\title{
Karakteristik Klinis dan Patologis Karsinoma Nasofaring di Bagian THT-KL RSUP Dr.M.Djamil Padang
}

\author{
Shofi Faiza', Sukri Rahman ${ }^{2}$, Aswiyanti Asri ${ }^{3}$
}

\begin{abstract}
Abstrak
Karsinoma nasofaring banyak terjadi di Cina dan Asia Tenggara, termasuk di Indonesia, sering didiagnosis pada keadaan lanjut dan memiliki prognosis yang buruk. Tujuan penelitian ini adalah untuk mengevaluasi epidemiologi, karakteristik klinis, dan tipe histopatologi pada pasien karsinoma nasofaring di Bagian THT-KL. Metodologi penelitian ini adalah deskriptif dengan menggunakan data rekam medik di RSUP Dr. M. Djamil Padang selama Juni 2010 sampai Juli 2013 dan data hasil pemeriksaan histopatologi sebagai konfirmasi. Didapatkan sebanyak 44 kasus yang lengkap pada periode tersebut, yang mana 52,27\% penderita adalah laki-laki dan 47,22\% perempuan, perbandingan laki-laki dan perempuan adalah 1,2:1. Sebaran umur penderita dari 17 sampai 75 tahun dengan insiden puncak pada umur 41- 65 tahun. Gejala klinis terdiri atas massa di leher 93,17\%, diikuti dengan obstruksi nasal 79,55\%, dan gangguan pendengaran 79,55\% sedangkan tanda klinis terdiri atas pembesaran kelenjar getah bening leher $90,91 \%$, diikuti dengan tuli 79,55\%, cranial nerve palsy dan perluasan kelenjar getah bening ke fossa supraklavikula masing-masing 15,8\%. Sebagian besar pasien berada pada stadium IV $83,16 \%$, dengan derajat tumor terbanyak T4N2M0 15,91\%. Tipe histopatologi yang terbanyak adalah nonkeratinizing carcinoma, undifferentiated type 75\%, diikuti keratinizing SCC 13,64\%, dan nonkeratinizing carcinoma differentiated type $11,36 \%$.
\end{abstract}

Kata kunci: karsinoma nasofaring, karakteristik klinis, histopatologi, padang

\begin{abstract}
Nasopharyngeal carcinoma is more frequent in China and Southeast Asia, including Indonesia, commonly with advance stages at diagnosis and has a poor prognosis. The objective of this study was to evaluate epidemiology, clinical characteristic and histopathology types of patients with nasopharyngeal carcinoma in the department of Otorhinolaryngology - Head and Neck Surgery. This is a descriptive study that used data from medical record of Dr. M. Djamil General Hospital in Padang during June 2010 to July 2013 and histopathology examination as confirmation. The result demonstrated 44 cases found on that period, of which 52,27\% was male and $47,72 \%$ was female, hence the male and female ratio was $1,2: 1$. The age-range from 17 to 75 years old with incidence peak between 41 - 65 years old. Clinical symptoms were neck mass $93,17 \%$, followed by nasal obstruction $79,55 \%$, and audiological complaints $79,55 \%$ while clinical sign were cervical lymphadenopathy 90,91\%, followed by hearing loss $79,55 \%$, cranial nerve palsy and lymphadenopathy metastases to fossa supraclavicular each subject 15,8\%. Most of patients were classified as stage IV 83,16\%, with T4N2M0 15,91\%. The histopathology type were nonkeratinizing carcinoma, undifferentiated type had percentage $75 \%$, followed by keratinizing SCC 13,64\%, and nonkeratinizing carcinoma - differentiated type $11,36 \%$.
\end{abstract}

Keywords: nasopharyngeal carcinoma, clinical characteristic, histopathology types, padang

Affiliasi penulis: 1. Pendidikan Dokter FK UNAND Fakultas Kedokteran Universitas Andalas Padang, 2. Bagian THT-KL FK UNAND/ RSUP Dr. M.Djamil Padang, 3. Bagian Patologi Anatomi FK UNAND
Korespondensi: Sukri Rahman, Bagian THT-KL FK UNAND/ RSUP.Dr.M. Djamil Padang, sukri rahman@yahoo.com 


\section{PENDAHULUAN}

Keganasan yang dalam istilah medis disebut kanker merupakan salah satu kasus kematian utama di dunia, termasuk di negara berkembang. Kanker juga merupakan hal yang paling dicemaskan oleh masyarakat saat ini. Dalam lingkupan medis, kanker menjadi kajian menarik karena masih banyak yang belum terungkap tentang penyakit ini. Berbagai teori telah dimunculkan untuk mekanisme terjadinya kanker, begitu juga dengan pengobatan serta prognosis yang belum memuaskan. Berdasarkan data WHO, di dunia terdapat $13 \%$ kematian disebabkan oleh kanker dan ada 100 jenis kanker yang bisa menyerang tubuh manusia. Sekitar $70 \%$ kematian oleh kanker berasal dari populasi negara dengan pendapatan rendah dan menengah. Di Indonesia, prevalensi kanker adalah 4,3 per 1.000 penduduk dan merupakan penyebab kematian nomor 7 (5.7\%) setelah stroke, tubekulosis, hipertensi, cedera, perinatal, dan diabetes mellitus. ${ }^{1,2}$

Salah satu masalah kanker yang sulit dideteksi dini adalah Karsinoma Nasofaring (KNF). KNF merupakan kanker yang mempunyai keunikan dan berbeda dari tumor ganas di daerah kepala dan leher lainnya dalam hal epidemiologi, spektrum gambaran histopatologi, karakteristik klinik dan sifat biologi. Hal ini terlihat dari kejadian KNF yang bersifat endemik di Asia seperti Cina Selatan, Asia Tenggara, Jepang, dan Timur Tengah. Insiden KNF tertinggi di dunia dijumpai pada penduduk daratan Cina bagian selatan, khususnya suku Kanton di provinsi Guang Dong dan daerah Guangxi dengan angka mencapai lebih dari 50 per 100.000 penduduk pertahun. Sementara insiden KNF di dunia tergolong jarang, yaitu $2 \%$ dari seluruh karsinoma sel squamous kepala dan leher, dengan insiden 0.5 sampai 2 per 100.000 di Amerika Serikat. ${ }^{3,4}$ Berdasarkan data registrasi kanker berbasis rumah sakit di RS Kanker Dharmais tahun 2003-2007 didapatkan bahwa KNF berada diperingkat ketiga setelah karsinoma mamae dan serviks, sementara untuk kanker terbanyak pada pria, KNF berada diperingkat pertama dan pada wanita berada diperingkat kelima. ${ }^{5}$

KNF dapat mengenai berbagai umur, tersering umur 40-60 tahun. Mulai meningkat setelah umur 20 tahun dan menurun setelah umur 60 tahun. Angka kejadian KNF pada anak bervariasi antara 1-5 \% dari seluruh kejadian kanker pada anak. Pria lebih banyak daripada wanita, yaitu $3: 10^{6,7}$ Sementara penyebab KNF bersifat multifaktorial, dikaitkan dengan adanya interaksi antara infeksi kronik oncogenic gamma herpesvirus Epstein-Barr virus yang mana virus Epstein-Barr telah menginfeksi lebih dari 95\% populasi dunia. Selain itu faktor lingkungan dan faktor genetik, juga terlibat dalan proses multistep karsinogenik. ${ }^{3}$

Data epidemiologi menyebutkan bahwa ras Mongoloid memiliki angka kejadian yang tinggi untuk menderita karsinoma nasofaring. Masyarakat Indonesia yang sebagian besar termasuk dalam ras Mongoloid serta memiliki kebiasaan mengonsumsi ikan asin yang merupakan salah satu dari 9 bahan makan pokok masyarakat Indonesia. Ikan asin memiliki kandungan nitrosamin yang merupakan salah satu faktor pencetus kanker ini. Nitrosamin juga diteliti terkandung dalam beberapa jenis makanan yang diawetkan, seperti daging olahan. Nitrosamin merupakan mediator utama yang dapat mengaktifkan virus Epstein-Barr yang memicu mekanisme kanker. Berdasarkan studi genetik juga terdapat adanya hubungan antara alel Human Leukocyt Antigen (HLA) kelas I dan II dalam populasi dan risiko KNF. ${ }^{8,6}$

Gejala dan tanda klinis yang sering ditemu-kan pada KNF diantaranya epistaksis, obstruksi hidung, tinnitus serta tuli, sefalgia, gejala saraf kranial, diplopia, pembesaran KGB leher dan gejala metastasis jauh dengan lokasi tersering adalah ke tulang, paru-paru, hati dan sering juga terjadi metastasis pada banyak organ sekaligus. ${ }^{9}$

Klasifikasi WHO tahun 1978 membagi KNF menjadi squamous cell carcinoma (WHO tipe 1), nonkeratinizing carcinoma (WHO tipe 2) dan undifferentiated carcinoma (WHO tipe 3). Klasifikasi yang saat ini digunakan adalah WHO tahun 1991 yang membagi tumor ganas ini menjadi squamous cell carcinoma (keratinizing SCC), nonkeratinizing carcinoma yang terdiri atas differentiated dan undifferentiated, dan basaloid SCC. Batasan antara subtipe ini terkadang tidak jelas, bahkan beberapa peneliti melaporkan bahwa SCC dan nonkeratinizing carcinoma sebenarnya adalah varian dari satu 
kelompok tumor yang homogen. Berdasarkan laporan dari berbagai negara, KNF subtipe undifferentiated carcinoma (termasuk nonkeratinizing carcinoma) adalah subtipe yang terbanyak ditemukan yaitu, Hong Kong (99\%), Singapore (83\%), Tunisia (92\%), Jepang (87\%) dan Amerika Serikat (75\%). ${ }^{10,11}$

Penelitian yang dilakukan Piasiska (2010) di Medan tahun 2009 didapatkan subtipe terbanyak adalah WHO - 3 (Undifferentiated subtype) sebesar $51,63 \% .{ }^{12}$ Data dari bagian Patologi Anatomi Fakultas Kedokteran Universitas Andalas tahun 2006-2008 didapatkan sebanyak 45 kasus KNF di Sumatera Barat, dengan subtipe terbanyak adalah subtipe WHO2 (Nonkeratinizing Carcinoma) dan WHO-3 (Undifferentiated subtype). ${ }^{13}$

Penanggulangan KNF sampai saat ini masih merupakan suatu masalah yang cukup sulit. Hal ini karena etiologinya yang masih belum pasti. Selain itu letak nasofaring yang cukup tersembunyi sehingga sulit untuk mendeteksinya. Gejala dini dari penyakit ini sering tidak jelas dan tidak khas sehingga sering diabaikan. Sebagian besar gejala klinis baru bermanifestasi setelah tumor bermetastasis ke kelenjar getah bening (KGB) leher. Mutlak dilakukan biopsi histopatologis sebagai konfirmasi diagnosis kanker ini. Pemeriksaan biopsi nasofaring sering ditemukan hasil yang negatif karena letak tumor yang tersembunyi mempersulit pengambilan dan penanganan oleh dokter. ${ }^{14}$

Pada stadium awal, pengobatan standar untuk KNF adalah radioterapi karena sifatnya yang radiosensitif. Pembedahan tidak berperan besar untuk mengobati karsinoma nasofaring tetapi dapat membantu dalam mengangkat sisa nodul di leher setelah diradiasi. Sementara kemoterapi memberikan harapan dalam meningkatkan kontrol tumor dan survival pada KNF stadium lanjut. ${ }^{14}$

Penelitian yang dilakukan Kurniawan (2011) mengenai angka harapan hidup dua tahun dari 56 kasus didapatkan pasien KNF dengan kemoradiasi secara keseluruhan sebesar $60 \%$. Pada bulan ke 24 , pasien stadium II memiliki angka harapan hidup diatas $80 \%$, pasien stadium IV sebesar $60 \%$, dan pasien stadium III hanya sebesar 40\%. Tidak terdapat perbedaan yang bermakna pada angka harapan hidup dua tahun pasien KNF antara stadium II, III, dan IV yang dilakukan terapi kemoradiasi. ${ }^{15}$ Kegagalan pengobatan ini disebabkan oleh perluasan lokoregional (40-80\% pasien) dan kekambuhan (15$50 \%$ pasien). ${ }^{16}$

Terlihat bahwa karsinoma nasofaring merupakan kanker kepala dan leher yang paling sering ditemukan pada masyarakat kita dengan faktor risiko yang tinggi untuk menderita penyakit ini baik dari segi ras, geografis dan kebiasaan.Penderita karsinoma nasofaring sering lambat terdeteksi karena faktor lokasi tumor, gejala yang tidak khas dan biopsi yang sulit sehingga menyebabkan buruknya prognosis dari penyakit ini.

\section{METODE}

Penelitian yang dilakukan bersifat deskriptif dengan menggunakan data rekam medik di RSUP Dr. M. Djamil Padang dari Oktober sampai Desember 2013. Sampel penelitian adalah data semua pasien dengan diagnosis akhir karsinoma nasofaring yang dirawat di Bangsal THT-KL RSUP Dr. M. Djamil Padang dari Juni 2010 sampai Juli 2013 berupa identitas pasien, status rawat inap / jalan pasien, hasil pemeriksaan klinis, histopatologi dan diagnostik. Data yang diperoleh diolah dan dikelompokkan secara manual dan komputerisasi dalam bentuk tabel distribusi frekuensi dan diagram batang.

\section{HASIL}

Ada 44 kasus KNF yang diteliti, yang terdiri dari $52,27 \%$ penderita adalah laki-laki dan 47,72\% adalah perempuan (Tabel 1). Penderita terbanyak ditemukan pada dewasa tua dengan kisaran umur 41-65 tahun sebesar $68,18 \%$, diikuti oleh dewasa muda dengan kisaran umur 21- < 41 tahun sebesar 24,99\%, kemudian remaja dengan kisaran umur 13- $<21$ tahun sebesar $4,54 \%$, dan kisaran umur yang paling sedikit ditemukan pada manula dengan umur > 65 tahun sebesar $2,27 \%$.

Bayi, balita dan anak-anak tidak ditemukan dalam sampel. Sesuai dengan distribusi umur menurut jenis kelamin laki-laki terbanyak ditemukan pada dewasa tua dengan kisaran umur 41-65 tahun sebesar 
40,91\%. Perempuan ditemukan terbanyak pada dewasa tua dengan kisaran umur 41-65 tahun sebesar $27,27 \%$ (Tabel 1)

Tabel 1. Distribusi frekuensi penderita karsinoma nasofaring menurut umur dan jenis kelamin

\begin{tabular}{ccccccc}
\hline Umur & \multicolumn{2}{c}{ Laki -laki } & \multicolumn{2}{c}{ Perempuan } & \multicolumn{2}{c}{ Total } \\
\cline { 2 - 7 } (tahun) & $\mathbf{f}$ & $\%$ & $\mathbf{f}$ & $\%$ & $\mathbf{f}$ & $\%$ \\
\hline $0-<1$ & - & - & - & - & - & - \\
$1-<5$ & - & - & - & - & - & - \\
$5-<13$ & - & - & - & - & - & - \\
$13-<21$ & - & - & 2 & $4,54 \%$ & 2 & $4,54 \%$ \\
$21-<41$ & 5 & $11,36 \%$ & 6 & $13,63 \%$ & 11 & $24,99 \%$ \\
$41-65$ & 18 & $40,91 \%$ & 12 & $27,27 \%$ & 30 & $68,18 \%$ \\
$>65$ & 0 & $0.00 \%$ & 1 & $2,27 \%$ & 1 & $2,27 \%$ \\
\hline Total & $\mathbf{2 3}$ & $\mathbf{5 2 , 2 7} \%$ & $\mathbf{2 1}$ & $\mathbf{4 7 , 7 2} \%$ & $\mathbf{4 4}$ & $\mathbf{1 0 0} \%$ \\
\hline
\end{tabular}

Gejala klinis terbanyak ditemukan adalah massa di leher sebesar 90,91\%. Obstruksi hidung dan gangguan pendengaran ditemukan sebesar 79,55\%, epistaksis sebesar 68,18\%, sakit kepala sebesar $63,64 \%$, dan tinnitus sebesar 56,82\%. Gejala klinis berupa diplopia sebesar $38,64 \%$, otorea sebesar $31,82 \%$, dan ptosis sebesar $22,73 \%$. Gejala klinis berupa rinore, otalgia, deviasi lidah, trismus, penglihatan kabur, dan eksoftalmus masing-masing ditemukan lebih kecil dari 20\%.(Tabel 2)

Tabel 2. Distribusi penderita karsinoma nasofaring menurut gejala klinis

\begin{tabular}{lcc}
\hline \multicolumn{1}{c}{ Gejala klinis } & $\mathbf{f}$ & $\%$ \\
\hline Massa leher & 40 & $90.91 \%$ \\
\hline Hidung : & 30 & $68.18 \%$ \\
Epistaksis & 35 & $79.55 \%$ \\
Obstruksi Hidung & 7 & $15.91 \%$ \\
Rinore & & \\
\hline Telinga : & & $79.55 \%$ \\
Gangguan & 35 & \\
pendengaran & 25 & $56.82 \%$ \\
Tinnitus & 1 & $2.27 \%$ \\
Otalgia & 14 & $31.82 \%$ \\
Otorea & & \\
\hline Saraf kranial : & 14 & $31.82 \%$ \\
Paresis Wajah & 2 & $4.55 \%$ \\
Deviasi lidah & 4 & $9.09 \%$ \\
Trismus & & \\
\hline Mata : & 17 & $38.64 \%$ \\
Diplopia & 5 & $11.36 \%$ \\
Pengliharan kabur & 10 & $22.73 \%$ \\
Ptosis & 2 & $4.55 \%$ \\
Eksoftalmus & 28 & $63.64 \%$ \\
\hline Nyeri Kepala & & \\
\hline & & \\
\hline & & \\
\hline & & \\
\hline
\end{tabular}

Tanda klinis terbanyak yang ditemukan pada penderita KNF adalah pembesaran KGB leher sebesar 93,17\% tuli sebesar $79,54 \%$. Diikuti dengan tuli sebesar $79,54 \%$, cranial nerve palsy dan perluasan KGB leher ke fossa supraklavikula masing-masing sebesar 29,55\%. Dermatomiositis tidak ditemukan pada penelitian ini.(Tabel3)

Tabel 3. Distribusi penderita karsinoma nasofaring menurut tanda klinis

\begin{tabular}{lcc}
\hline \multicolumn{1}{c}{ Tanda klinis } & $\mathbf{f}$ & $\%$ \\
\hline Pembesaran KGB leher & 40 & $90.91 \%$ \\
Perluasan KGB leher ke fossa & 13 & $29.55 \%$ \\
supraklavikula & & \\
Cranial nerve palsy & 13 & $29.55 \%$ \\
Tuli & 35 & $79.55 \%$ \\
Dermatomiositis & 0 & $0.00 \%$ \\
\hline
\end{tabular}

Pada Gambar 1 terlihat penderita umumnya datang pada stadium IV sebesar $75 \%$. Diikuti penderita yang datang pada stadium II ditemukan sebanyak 13,64\%. Penderita yang datang pada stadium III sebesar $11,36 \%$ dan tidak ada pasien yang datang pada stadium I. Pada penelitian ini ditemukan juga sebesar $11,36 \%$ pasien yang berada pada stadium IV C yang mengalami metastasis jauh ke organ seperti paru-paru, tulang dan ginjal (Gambar 1).

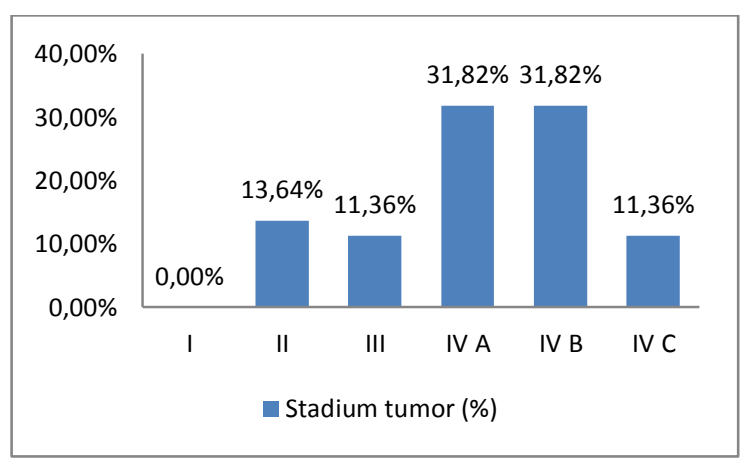

Gambar 1. Distribusi penderita karsinoma nasofaring menurut stadium tumor

Hasil penelitian ditemukan tipe histopatologi terbanyak adalah Nonkeratinizing carcinomaundifferentiated type, sebesar 75\%.Keratinizing Squamous Cell Carcinoma ditemukan sebanyak $13,64 \%$ dan Nonkeratinizing carcinoma-differentiated type sebesar 11,36\%. Sedangkan Basaloid Squamous 
Cell Carcinoma tidak ditemukan dari seluruh penderita.(Gambar 2).

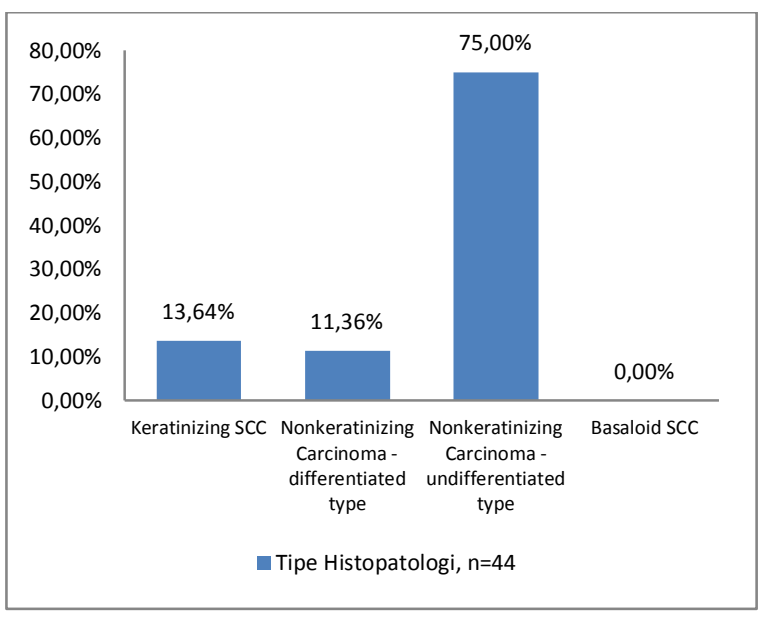

Gambar 2. Distribusi penderita karsinoma nasofaring menurut tipe histopatologi

\section{PEMBAHASAN}

Perbandingan penderita laki-laki dengan perempuan adalah 1,2: 1. Penelitian Yenita dan Asri (2010) di Sumatera Barat mendapatkan perbandingan 2 : $1 .^{13} \mathrm{Di}$ Amerika Serikat didapatkan angka perbandingan $2: 1^{17} \mathrm{KNF}$ selalu lebih tinggi ditemukan pada laki-laki. Belum ditemukan secara pasti penyebab tingginya penderita laki-laki daripada perempuan pada kanker ini. Laki-laki mungkin cenderung lebih sering terpapar zat-zat karsinogen di lingkungan kerjanya dibanding perempuan sehingga lebih berisiko untuk menderita kanker.

Pada penelitian ini secara keseluruhan didapatkan kisaran umur antara 17 - 75 tahun. Penderita berumur dibawah 20 tahun tergolong rendah yaitu 4,54\%. Di Departemen IKA RSCM, KNF berada pada urutan ke-10 dan berkontribusi 2\% (24 dari 1194 pasien) seluruh kanker pada anak tahun 2004-2009. ${ }^{18}$ KNF pada anak diduga berkaitan erat dengan peran infeksi EBV. Peningkatan titer antibodi immunoglobulin $G$ dan $A(\lg G$ dan $\lg A)$ terhadap antigen kapsid viral ditemukaan pada pasien KNF. ${ }^{19}$ Adanya faktor genetik, lingkungan dan kebiasaan hidup, dan infeksi berperan sebagai kontributor dominan terhadap kejadian KNF ini masih memerlukan penelitian lanjut. ${ }^{20}$

Massa di leher merupakan gejala klinis terbanyak yang ditemukan pada penderita sebesar $90,91 \%$. Massa di leher menunjukkan telah terjadinya perluasan tumor ke kelenjar getah bening (KGB). KNF biasanya menyebar melalui limfe ke KGB leher. Aliran limfatik dari Fossa Rossenmuller mengalir ke Nodus Rouvier sampai ke ruang retrofaringeal dan berlanjut ke KGB leher atas dalam. Hal ini menjelaskan bahwa massa di leher sering menjadi gejala klinis dari KNF yang membuat pasien berobat ke dokter. Kanker ini akan menyebar melalui aliran darah ke daerah yang jauh seperti tulang, paru dan hati. ${ }^{21}$ Obstruksi hidung dikarenakan massa tumor yang telah menginvasi rongga hidung atau sinus paranasal. Massa tumor yang awalnya tumbuh di daerah Fossa Rossenmuller biasanya akan menginfiltrasi daerah tuba eustachius di dekatnya dan menyebabkan penyumbatan tuba dan bermanifestasi klinis terhadap menurunnya pendengaran. Kesulitan dalam menelan biasanya dikarenakan massa tumor yang telah menginvasi daerah orofaring dan menekan saraf daerah tenggorok. Sakit kepala biasanya diakibatkan oleh gejala neurologis yang diikuti gejala mata pada KNF akibat inflasi tumor ke daerah otak, mata dan juga gejala psikologis yang diakibatkan tumor. ${ }^{21}$

Pada pemeriksaan klinis, pasien yang ditemukan dengan keadaan pembesaran KGB leher sebesar 90,91\%. Tanda klinis lainnya adalah tuli sebesar $79,55 \%$, diikuti dengan pembesaran KGB leher ke fossa supraklavikula dan cranial nerve palsy yang masing-masing sebesar 29,55 \%. Persentase ini berbeda dengan data di RS Pamela Youde Nethersole Western Hospital, Hong Kong dari tahun 1994 - 2001, yaitu pembesaran KGB leher unilateral merupakan terbanyak sebesar $72 \%$, diikuti dengan pembesaran KGB leher bilateral sebesar 35\%, kemudian perluasan KGB leher ke fossa supraklavikula sebesar $12 \%$, cranial nerve palsy $10 \%$, tuli sebesar $3 \%$, dan dermatomiositis sebesar 1\%. Untuk daerah yang sangat endemik dapat ditemukan tanda klinis dermatomiositis pada pasien KNF, hal ini berkaitan dengan tingginya risiko pasien dermatomiositis untuk menderita KNF. ${ }^{11}$ Dalam penelitian ini tidak ditemukan dermatomiositis.

Studi terakhir membuktikan rendahnya kesadaran terhadap gejala dan tanda awal KNF pada tenaga medis di Indonesia. Tersembunyinya lokasi tumor dan diperlukannya pemeriksaan khusus di Rumah Sakit yang memiliki fasilitas lengkap juga 
mempersulit deteksi awal dari kanker ini. ${ }^{21}$ Pada dasarnya, pemeriksaan dan biopsi tumor nasofaring perlu dilakukan dengan pemeriksaan nasoendoskopi. Pengetahuan tentang tanda dan gejala yang paling sering timbul membantu klinisi untuk lebih cepat mendiagnosis tumor yang ada, sehingga dapat meningkatkan pilihan pengobatan. ${ }^{22}$ Adanya keterlambatan diagnosis terkait dengan ketidaksadaran pasien terhadap KNF dan kecenderungan pasien mencari obat tradisional sebagai pengobatan pertama. $^{21}$

Pada penelitian ini didapatkan penderita datang dengan stadium lanjut sebesar $86,36 \%$, yang terdiri atas stadium IV dan III, diikuti stadium awal yaitu stadium II sebesar 13,64\%, sedangkan stadium I tidak ditemukan. Hal ini memperlihatkan bahwa penderita biasanya telah datang dalam keadaan stadium lanjut dengan gambaran penderita terbanyak berupa massa tumor yang telah menginvasi intrakranial dengan melibatkan nervus kranial, fossa infratemporal, hipofaring, orbit, atau ruang mastikator yang dapat dilihat pada hasil pemeriksaan CT Scan. Adanya pembesaran kelenjar getah bening leher bilateral di atas fossa supraklavikula dengan ukuran kurang lebih $6 \mathrm{~cm}$ dan tidak terdapat metastasis berdasarkan foto thorax.

Hasil pemeriksaan tipe histopatologi yang juga sebagai konfirmasi diagnosis, jenis KNF yang paling banyak ditemukan adalah nonkeratinizing carcinomaundifferentiated type sebesar 72,73\%. Untuk keratinizing SCC sebesar $13,64 \%$ dan nonkeratinizing carcinoma-differentiated type sebesar 11,36\%. Penelitian Yenita dan Asri (2010) terhadap kasus KNF di Sumatera Barat berdasarkan WHO 1978 mendapatkan WHO-3 sebagai tipe terbanyak sebesar 68\%. WHO-3 merupakan undifferentiated carcinoma, yang mana karsinoma anaplastik masuk kedalam tipe ini. Sementara dalam klasifikasi WHO 1991, tipe WHO-3 masuk ke dalam jenis nonkeratinizing carcinomaundifferentiated type.Walaupun terdapat perbedaan angka, terlihat bahwa nonkeratinizing carcinomaundifferentiated type merupakan tipe histopatologi yang terbanyak ditemukan pada KNF. ${ }^{13}$

Tumor rongga mulut, tumor rongga hidung dan tumor laring yang diyakini berhubungan dengan konsumsi rokok dan alkohol, lebih dari 75\% merupakan karsinoma sel skuamosa. Undifferentiated type merupakan yang terbanyak dalam prevalensi KNF di Asia Tenggara dan beberapa daerah dengan insiden KNF yang tinggi, dan sangat berhubungan dengan infeksi EBV. Sedangkan keratinizing SCC dapat juga dihubungkan dengan EBV di daerah endemik, dan banyak terdapat di daerah non-endemik seperti Amerika, yang sering dihubungkan dengan perokok dan pecandu alcohol. ${ }^{23}$

\section{KESIMPULAN}

Perbandingan penderita laki-laki dan perempuan adalah 1,2:1, dengan sebaran umur mulai dari 17 sampai 75 tahun. Penderita terbanyak ditemukan pada kelompok umur 41 sampai 65 tahun. Pembesaran kelenjar getah bening leher merupakan tanda dan gejala klinis terbanyak yang ditemukan pada seluruh penderita.

Mayoritas penderita datang pada stadium lanjut (stadium IV dan III), diikuti stadium II ,stadium I tidak ditemukan, terdapat pasien yang mengalami metastasis jauh ke paru-paru, tulang, dan ginjal.

Tipe histopatologis terbanyak adalah bentuk nonkeratinizing carcinoma - undifferentiated type, diikuti keratinizing, nonkeratinizing carcinoma differentiated type, sedangkan basaloid SCC tidak ditemukan.

\section{DAFTAR PUSTAKA}

1. WHO. 10 facts about cancer. 2013 (diunduh 5 Mei 2013). Tersedia dari: URL: HYPERLINK http://www.who.int/features/factfiles/cancer/en/inde x.html

2. Riskesdas. Laporan nasional 2007 badan penelitian dan pengembangan kesehatan Departemen Kesehatan RI; 2007

3. Zhou XJ, Cui AA, Kajdacsy BH, Ye J, Wang PN, Rao. The progress on genetic analysis of nasopharyngeal carcinoma. Comparative and Functional Genomics; 2007.

4. Chang ET, Adami HO. The enigmatic epidemiology of nasopharyngeal carcinoma. Cancer Epidemiology Biomarkers and Prevention. 2006;15(10):1765-77. 
5. RKSD. Laporan kerja subbagian registrasi kanker bagian penelitian dan pengembangan RSKD. Pusat Kanker Nasional Departemen Kesehatan Republik Indonesia. Jakarta; 2010 (diunduh 5 Mei 2013). Tersedia dari: URL: HYPERLINK http://indonesianjournalofcancer.org/

6. Chan ATC, Teo PML, Johnson PJ Nasopharyngeal carcinoma. Dalam: B.Brockstein Head and Neck Cancer. New York: Kluwer Academic. hlm.275-91.

7. Haleema Saeed AZ, Mehreen A, Rabia H, Amber D. Pediatric Nasopharyngeal carcinoma: a review of 27 cases over 10 years at Shaukat Khanum Memorial Cancer Hospital and Research Center, Pakistan. As Pac J Cancer Prevent. 2009;10:91720.

8. Roezin, Averdi, Syafril A. Karsinoma nasofaring. Dalam: Soepardi EA, Iskandar N, editor (penyunting). Buku Ajar IImu Kesehatan Telinga Hidung Tenggorokan Kepala \& Leher. Edisi Ke-6. Jakarta: Balai Penerbit FKUI; 2006.

9. Desen W. Tumor di kepala dan leher. Dalam: Buku Ajar Onkologi Klinis. Edisi ke-2. Jakarta: Balai Penerbit FKUI; 2008. hlm.263-78.

10. Kumar V, Cotran RS, Robbins SL. Robbins basic pathology. Edisi ke-7. Philadelphia: Elsevier Saunders; 2003.

11. WHO. Pathology and genetics of head and neck tumours. IARC Press.Lyon. 2005.

12. Piasiska $\mathrm{H}$. Profil penderita karsinoma nasofaring di laboratorium patologi anatomi kota Medan tahun 2009 (tesis). Medan: Fakultas Kedokteran Universitas Sumatera Utara; 2010.

13. Yenita, Asri A. Studi retrospektif karsinoma nasofaring di Sumatera Barat : reevaluasi subtipe histopatologi berdasarkan klasifikasi WHO. Padang: Fakultas Kedokteran Universitas Andalas; 2010.

14. Lu Jiade J, Jay S, Cooper, Anne, WM, Lee. Nasopharyngeal cancer: multidiciplinary management. London: Springer-Verlag; 2010.

15. Kurniawan R. Angka harapan hidup dua tahun penderita karsinoma nasofaring pada berbagai stadium yang dilakukan terapi kemoradiasi (skripsi). Semarang: Fakultas Kedokteran Universitas Diponegoro; 2011.

16. Farias TP, et al. Prognostic factors and outcome for nasopharyngeal carcinoma. Arch ortholaryngol head neck surg. 2003;129:794-9.

17. Globocan. CA. Cancer J Clin. 2011;61:69-90. Tersedia dari: URL: HYPERLINK http://globocan. iarc.fr/Pages/fact sheets cancer.aspx

18. Amelia C, Novie, et al. Karsinoma nasofaring pada anak: karakteristik, tata laksana, dan prognosis. Dalam: Sari Pediatri. 2011;13(1).

19. Brays F, Haugen M, Moger TA, Tretli S, Aalen OO, Grotmol T. Age-incidence curves of nasopharyngeal carcinoma worldwide: bimodality in low-risk populations and aetiologic implications. Dalam: Cancer Epidemiol. Biomark; 2008. hlm. 2356-64.

20. Sultan .I, Casanova M, Ferrari A, Rihani R, Rodriguez-Galindo C. Differential features of nasopharyngeal carcinoma in children and adults : a SEER study. Pediatr. Blood Cancer. 2010; 55: 279-81.

21. Alan Soo-Beng Khoo, Kin-Choo Pua, Diagnosis and Clinical Evaluation of Nasopharyngeal Carcinoma. In Nasopharyngeal Carsinoma Keys for Translational Medicine and Biology. Springer, 2013.

22. Marlinda Adham, et al, Nasopharyngeal carcinoma in Indonesia: epidemiology, incidence, signs, and symptoms at presentation. Chinese Journal of Cancer. 2012;31(4).

23. Nicholls J, Niedobitek G. Histopathological diagnosis of nasopharyngeal carcinoma: looking beyong the blue book. Dalam: Nasopharyngeal Carsinoma Keys for Translational Medicine and Biology. Springer; 2013. 